\title{
PERBEDAAN KEMAMPUAN PEMAHAMAN KONSEP MATEMATIKA SISWA MENGGUNAKAN MODEL PEMBELAJARAN PROBLEM BASED LEARNING DENGAN MODEL PEMBELAJARAN DISCOVERY LEARNING BERBANTUAN CABRI 3D
DI KELAS VIII SMP NEGERI 27 MEDAN
}

\author{
Nina Richi N, Mukhtar \\ Prodi Pendidikan Matematika, Fakultas Matematika dan Ilmu Pengetahuan Alam, \\ Universitas Negeri Medan (UNIMED), 20221Medan, Sumatera Utara, Indonesia \\ Email:nninarichi05@gmail.com
}

\begin{abstract}
ABSTRAK
Penelitian eksperimen semu ini bertujuan untuk melihat bahwa kemampuan pemahaman konsep matematika siswa yang belajar dengan model pembelajaran Problem Based Learning Berbantuan Cabri 3D lebih tinggi daripada siswa yang belajar dengan model pembelajaran Discovery Learning Berbantuan Cabri 3D di kelas VIII SMP Negeri 27 Medan T.A 2016/2017. Penelitian ini menggunakan posttest control design dengan populasi seluruh siswa kelas VIII SMP Negeri 27 Medan tahun ajaran 2016/2017 dan sampel penelitian adalah siswa kelas VIII-4 dan VIII-6 yang dipilih dengan teknik cluster sampling. Data penelitian diperoleh melalui tes uraian. Berdasarkan hasil perhitungan dapat disimpulkan bahwa kemampuan pemahaman konsep matematika siswa yang belajar dengan model pembelajaran Problem Based Learning Berbantuan Cabri 3D lebih tinggi dibandingkan dengan siswa yang belajar dengan model pembelajaran Discovery Learning Berbantuan Cabri 3D di kelas VIII SMP Negeri 27 Medan T.A 2016/2017.

Kata Kunci : Pemahaman Konsep Matematika, Problem Based Learning, Discovery Learning, Cabri $3 D$
\end{abstract}

\begin{abstract}
This quasi experimental research aimed to know understanding of mathematical concepts using Problem Based Learning model assisted by Cabri 3D was better than understanding of mathematical concepts using Discovery Learning model assisted by Cabri 3D in grade eight of SMP Negeri 27 Medan in academic year of 2016/2017. This research used posttest control design with population was all students of grade eight of SMP Negeri 27 Medan in academic year of 2016/2017and samples were students of VIII4 and VIII-6 class that were chosen by cluster sampling. The data of research were obtained by essay test. Based on the result of research, it could be concluded that the understanding of mathematical concepts using Problem Based Learning model assisted by Cabri $3 D$ was better than understanding of mathematical concepts using Discovery Learning model assisted by Cabri 3D in grade eight of SMP Negeri 27 Medan in academic year of 2016/2017.

Keywords: Understanding of mathematical concepts, Problem Based Learning model, Discovery Learning model, Cabri $3 D$.
\end{abstract}

Nina Richi N, Mukhtar. Perbedaan Kemampuan Pemahaman Konsep Matematika Siswa Menggunakan Model Pembelajaran Problem Based Learning dengan Model Pembelajaran Discovery Learning Berbantuan Cabri $3 d$ di Kelas VII SMP Negeri 27 Medan. Jurnal Inspiratif, Vol. 3, No. 1 April 2017. 


\section{Pendahuluan}

Salah satu aspek yang terkandung dalam pembelajaran matematika adalah konsep. Akan sangat sulit bagi siswa untuk menuju ke proses pembelajaranyang lebih tinggi jika belum memahami konsep. Oleh karena itu, kemampuan pemahaman konsep menjadi tujuan pembelajaran matematika yang pertama sesuai Permendikbud Nomor 58 Tahun 2014 yang menyatakan bahwa pemahaman konsep merupakan kemampuan siswa untuk memahami konsep matematika, menjelaskan keterkaitan antar konsep dan mengaplikasikan konsep atau algoritma, secara luwes, akurat, efisien, dan tepat dalam pemecahan masalah. Sehingga dapat dikatakan bahwa seseorang siswa memiliki pemahaman konsep yang baik apabila mampu menjelaskan kembali konsep yang telah dipelajari, memberikan contoh dan bukan contoh dari konsep serta menggunakan konsep dalam pemecahan masalah.

$\begin{array}{lr}\text { Pemahaman } & \text { konsep } \\ \text { merupakan dasar utama }\end{array}$
pembelajaran matematika. Menurut Dewi ( 2014:94), pemahaman konsep matematika dapat diartikan dalam suatu proses pengamatan yang tidak langsung dalam menyerap pengertian dari konsep/ teori yang akan dipahami dan mempertunjukkan kemampuannya di dalam menerapkan konsep/ teori yang akan dipahami pada keadaan atau situasi permasalahan yang lebih luas. Sejalan dengan itu, Hudojo (2005:107) juga menyatakan bahwa belajar matematika itu memerlukan pemahaman terhadap konsep-konsep, konsep-konsep ini akan melahirkan teorema atau rumus. Agar konsep-konsep dan teorema-teorema dapat diaplikasikan ke situasi yang lain, perlu adanya keterampilan menggunakan konsep-konsep dan teorema-teorema tersebut. Oleh karena itu, pembelajaran matematika harus ditekankan ke arah pemahaman konsep.

Namun pada kenyataannya banyak siswa yang kesulitan dalam memahami konsep matematika. Rendahnya kemampuan pemahaman konsep siswa terhadap matematika terlihat dari cara siswa dalam menyelesaikan soal-soal yang diberikan guru. Siswa masih belum dapat mengungkapkan kembali dengan lengkap konsep yang telah dipelajari, begitu juga menggunakan konsep dalam pemecahan masalah, masih banyak ditemukan siswa kesulitan dalam menjawab soal-soal yang diberikan guru, dikarenakan siswa tidak paham menggunakan konsep yang mana untuk pemecahan masalah tersebut. Hal ini disebabkan karena selama ini, pembelajaran yang laksanakan di dalam kelas lebih kepada latihan soal-soal dan diskusi yang berpusat pada guru, belum memaksimalkan keaktifan siswa dalam proses pembelajaran. Selain itu, penyebab kurangnya pemahaman siswa terhadap suatu konsep adalah pembelajaran yang terpusat pada guru.

Untuk mencapai pemahaman konsep siswa dalam matematika,maka kegiatan pembelajaran harusnya tidak hanya sekedar kegiatan mentransfer pengetahuan dari guru kepada siswa, tetapi juga dapat membuat siswa memaknai kegiatan belajar itu sendiri dan meningkatkan keaktifan siswa selama belajar mengajar berlangsung. Oleh karena itu, bentuk kegiatan pembelajaran yang dapat digunakan untuk meningkatkan kemampuan pemahaman konsep matematika siswa antara lain dengan model Problem Based Learning ataupun Discovery Learning.

Model pembelajaran Problem Based Learning merupakan model pembelajaran berdasarkan masalah nyata yang bersifat terbuka agar siswa dapat mengembangkan keterampilannya untuk

Nina Richi N, Mukhtar. Perbedaan Kemampuan Pemahaman Konsep Matematika Siswa Menggunakan Model Pembelajaran Problem Based Learning dengan Model Pembelajaran Discovery Learning Berbantuan Cabri 3d di Kelas VII SMP Negeri 27 Medan. Jurnal Inspiratif, Vol. 3, No. 1 April 2017. 
bisa menyelesaikan masalah tersebut. Rusman (2012:243) menyebutkan bahwa Problem Based Learning adalah suatu proses pembelajaran yang melibatkan siswa dalam penyelidikan pilihan sendiri yang memungkinkan mereka menginterpretasikan dan menjelaskan fenomena dunia nyata dan membangun pemahamanya tentang fenomena itu. Karena proses pembelajaran dengan model Problem Based Learning ini diawali dengan pemberian masalah dalam kehidupan sehari- hari, diharapkan siswa terbiasa untuk menganalisa, mengaplikasikan dan mengaitkan suatu konsep. Minarni (2016) dalam penelitiannya menyebutkan bahwa model pembelajaran Problem Based Learning dapat meningkatkan kemampuan pemahaman matematika siswa dan meningkatkan aktivitas siswa didalam kegiatan pembelajaran. Hal ini menunjukkan model pembelajaran Problem Based Learning dapat menjadi salah satu model pembelajaran pilihan guru untuk meningkatkan kemampuan pemahaman konsep matematika siswa. Selanjutnya, model pembelajaran Discovery Learning adalah suatu model pembelajaran yang menekankan pada kegiatan siswa untuk menemukan sesuatu. Menurut Wilcox dalam pembelajaran dengan penemuan, siswa didorong untuk belajar sebagian besar melalui keterlibatan aktif mereka sendiri dengan konsep-konsep dan prinsipprinsip, dengan melakukan percobaan ataupun observasi (Hosnan, 2014: 281). Selain itu, model pembelajaran Discovery Learning memberi keleluasaan bagi siswa untuk mengungkapkan pendapat berupa pernyataan ataupun pertanyaan, karena siswa tidak bergantung pada guru dalam hal memperoleh informasi, tetapi siswa juga dapat memanfaatkan lingkungan yang ada di sekitarnya sebagai sumber informasi.

Efektifitas suatu pembelajaran tidak hanya ditentukan oleh model pembelajaran yang digunakan, namun pemanfaatan media yang tepat akan memaksimalkan tujuan pembelajaran dan meningkatkan pemahaman siswa. Christou,C.,dkk (2006) mengungkapkan solusi untuk meningkatkan pemahaman siswa yaitu " dengan penggunaan komputer dalam pembelajaran matematika, khususnya pembelajaran geometri 3D akan dapat meningkatkan kemampuan visualisasi siswa dan memungkinkan mereka untuk memperoleh pemahaman yang lebih terhadap konsep- konsep matematika yang bersifat tiga dimensi." Dalam artian pemanfaatan media komputer akan memberikan kemudahan bagi peserta didik untuk membangun sendiri pengetahuan yang sedang dipelajarinya terlebih dalam pembelajaran geometri karena objek kajiannya berupa benda abstrak. Salah satu software dalam komputer adalah Cabri $3 D$ dimana software ini merupakan software interaktif matematika yang sangat berguna dalam belajar mengajar geometri 3 dimensi (Widiyaningsih, 2013). Atas dasar hal tersebut, peneliti melakukan pembelajaran matematika dengan menggunakan media berbasis komputer yaitu dengan software Cabri $3 D$ selama proses pembelajaran berlangsung di kelas. Hal tersebut dilakukan dengan alasan bahwa komputer mampu memvisualisasikan sebagian besar materi matematika dan kurikulum menuntut penggunaan komputer dalam pembelajaran matematika serta tampilan komputer lebih menarik dibandingkan dengan papan tulis.

Berdasarkan uraian di atas diduga bahwa kemampuan pemahaman konsep matematika siswa yang belajar dengan model pembelajaran Problem Based Learning dengan bantuan Cabri

Nina Richi N, Mukhtar. Perbedaan Kemampuan Pemahaman Konsep Matematika Siswa Menggunakan Model Pembelajaran Problem Based Learning dengan Model Pembelajaran Discovery Learning Berbantuan Cabri 3d di Kelas VII SMP Negeri 27 Medan. Jurnal Inspiratif, Vol. 3, No. 1 April 2017. 
$3 D$ lebih tinggi daripada siswa yang belajar dengan model pembelajaran Discovery Learning dengan bantuan Cabri 3D. Dikatakan demikian, sebab dalam model pembelajaran Problem Based Learning memerlukan peran guru lebih banyak dibanding dengan model Discovery Learning. Guru memiliki peran sebagai pendukung siswa untuk bisa menyelesaikan masalah yang dimaksud dengan usaha mereka sendiri. Pada Problem Based Learning guru memiliki tugas untuk membimbing secara langsung penyelidikan yang dilakukan siswa untuk menyelesaikan masalah yang diberikan. Jadi, dapat dikatakan bahwa guru memiliki peran lebih aktif pada model pembelajaran Problem Based Learning daripada model Discovery Learning.

Namun yang menjadi permasalahan adalah beberapa penelitian sebelumnya tidak menyatakan demikian. Seperti penelitian yang dilakukan oleh Rahayu (2015) yang menyatakan bahwa pembelajaran dengan model pembelajaran Discovery Learning lebih baik dari pembelajaran dengan model pembelajaran Problem Based Learning.

Karena adanya perbedaan hasil penelitian sebelumnya terhadap kemampuan pemahaman konsep matematika siswa yang menggunakan kedua model pembelajaran tersebut, sehingga perlu dilakukan penelitian yang bertujuan untuk mengetahui apakah kemampuan pemahaman konsep matematika siswa yang belajar dengan model pembelajaran Problem Based Learning berbantuan Cabri 3D lebih tinggi daripada siswa yang belajar dengan model pembelajaran Discovery Learning berbantuan Cabri 3D.

\section{Metode Penelitian}

Penelitian ini merupakan penelitian eksperimen semu dengan menggunakan desain penelitian posttest only control group design. Adapun Populasi dalam penelitian ini adalah siswa kelas VIII SMP Negeri 27 Medan tahun ajaran 2016/ 2017 yang terdiri dari 9 (sembilan) kelas. Dari 9 (sembilan) kelas VIII di SMP Negeri 27 Medan dipilih sebanyak 2 kelas sebagai sampel, yaitu kelas VIII-4 sebanyak 40 siswa sebagai kelas eksperimen 1 yang diajarkan dengan model Problem Based Learning berbantuan Cabri 3D dan kelas VIII-6 sebanyak 40 siswa sebagai kelas eksperimen 2 yang diajarkan dengan model Discovery Learning berbantuan Cabri $3 D$ diperoleh dengan pengambil sampel dengan cara Cluster Sampling.

Selanjutnya variabel penelitian terdiri dari dua variabel yaitu variabel terkat dan variabel bebas. Variabel terikatnya adalah kemampuan pemahaman konsep matematika siswa sementara variabel bebasnya adalah Model pembelajaran Problem Based Learning berbantuan Cabri $3 D$ dan model pembelajaran Discovery Learning berbantuan Cabri 3D. Tahapan dalam penelitian ini terdiri atas tahap persiapan, pelaksanaan, dan penilaian. Sebelum dilakukan penelitian dalam penelitian ini terlebih dahulu dilakukan validasi instrumen tes yang divalidkan oleh tiga validator dengan mempertimbangkan kesesuaian butir tes dengan indikator dari pemahaman konsep matematika serta memperhatikan keabsahan susunan kalimat atau katakata dalam soal.

\section{Hasil Penelitian}

\section{Deskripsi Hasil Penelitian}

Dari hasil posttest pemahaman konsep matematika yang diperoleh pada kelas eksperimen 1 dan kelas eksperimen 2 secara ringkas disajikan dalam Tabel 1

Nina Richi N, Mukhtar. Perbedaan Kemampuan Pemahaman Konsep Matematika Siswa Menggunakan Model Pembelajaran Problem Based Learning dengan Model Pembelajaran Discovery Learning Berbantuan Cabri 3d di Kelas VII SMP Negeri 27 Medan. Jurnal Inspiratif, Vol. 3, No. 1 April 2017. 
Tabel 1. Posttest Pemahaman Konsep Matematika Siswa

\begin{tabular}{|c|c|c|}
\hline \multirow{2}{*}{ Statistik } & \multicolumn{2}{|c|}{ Kelas } \\
\cline { 2 - 3 } & Eksperimen 1 & Eksperimen 2 \\
\hline Jumlah Siswa & 40 & 40 \\
\hline Nilai Maksimum $\left(\mathrm{X}_{\text {maks }}\right)$ & 100 & 94 \\
\hline Nilai Minimum $\left(\mathrm{X}_{\text {min }}\right)$ & 50 & 42 \\
\hline Rata- Rata & 76,95 & 68,175 \\
\hline Simpangan Baku & 14,08937 & 13,91713 \\
\hline
\end{tabular}

Tabel 1. menunjukkan data pada kelas eksperimen 1 dan kelas eksperimen 2 setelah dilakukan proses pembelajaran dengan model Problem Based Learning dan model Discovery Learning. Rentang nilai pada kelas eksperimen 1 yaitu 50 sedangkan pada kelas eksperimen 2 yaitu 52. Hal ini menunjukkan bahwa rentang kedua kelas tidak jauh berbeda. Nilai siswa tertinggi dari dua kelas tersebut terdapat pada kelas eksperimen 1 dengan nilai 100. Artinya pemahaman konsep matematika perorangan tertinggi terdapat di kelas eksperimen 1.

Jika dilihat dari nilai rata- rata yang diperoleh kedua kelas, kelompok eksperimen 1 lebih tinggi dibandingkan dengan kelas eksperimen 2 dengan selisih 8,775. Hal ini menunjukkan bahwa rata- rata skor pemahaman konsep kelas eksperimen 1 di atas ratarata skor pemahaman konsep kelas eksperimen 2. Simpangan baku skor pemahaman konsep matematika kelompok eksperimen 1 lebih tinggi dibandingkan kelompok eksperimen 2, hal ini berarti rata- rata penyimpangan nilai siswa kelas ekperimen 1 dari nilai rata- rata kelasnya lebih tinggi dibandingkan kelas eksperimen 2, atau dengan kata lain nilai siswa kelas eksperimen 1 lebih menyebar dibandingkan kelas eksperimen 2.

Berdasarkan perhitungan daftar nilai posttest kelas eksperimen 1 dan kelas eksperimen 2 perbandingan persebaran data di kedua kelas dapat dilihat pada gambar.

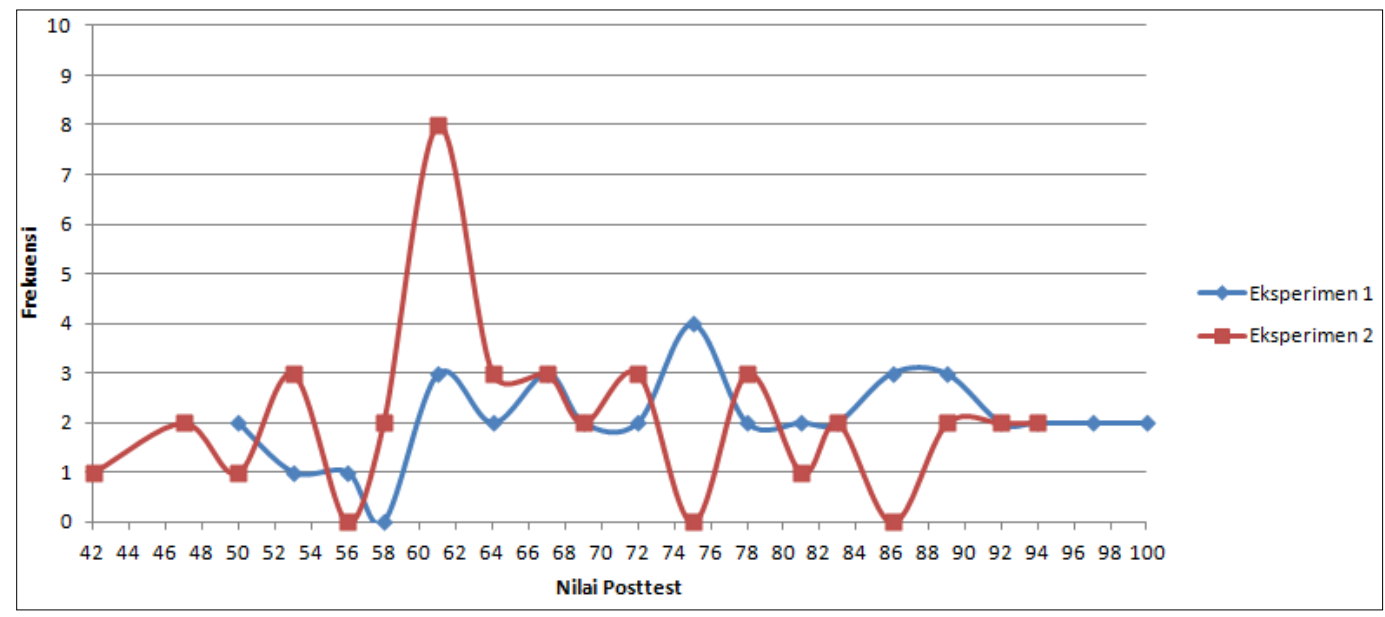

Gambar 1. Grafik Perbandingan Nilai Posttest Pemahaman Konsep Matematika Siswa Kelas Eksperimen 1 dan Kelas Eksperimen 2

Nina Richi N, Mukhtar. Perbedaan Kemampuan Pemahaman Konsep Matematika Siswa Menggunakan Model Pembelajaran Problem Based Learning dengan Model Pembelajaran Discovery Learning Berbantuan Cabri 3d di Kelas VII SMP Negeri 27 Medan. Jurnal Inspiratif, Vol. 3, No. 1 April 2017. 
Berdasarkan kurva di atas, terlihat bahwa nilai siswa tertinggi dari dua kelas tersebut terdapat pada kelas eksperimen 1 dengan nilai 100 , sedangkan nilai terendah terdapat pada kelas eksperimen 2 dengan nilai 42 . Selain itu, berdasarkan rata- rata, penyebaran nilai pemahaman konsep matematika siswa pada kelas eksperimen 1 cenderung mengumpul di atas nilai rata- rata kelas eksperimen 2 $(68,175)$. Hal tersebut menunjukkan bahwa kemampuan pemahaman konsep matematika siswa kelas eksperimen 1 lebih tinggi dibandingkan kemampuan pemahaman konsep matematika siswa kelas eksperimen 2.

\section{Hasil Penelitian}

\section{Uji Normalitas}

Uji normalitas data dilakukan dengan menggunakan uji Liliefors dengan syarat normal adalah $\mathrm{L}_{0}<\mathrm{L}_{\text {tabel }}$ pada taraf $\alpha=0,05$. Secara ringkas hasil pehitungan uji normalitas data posttest pada masing-masing kelas dapat dilihat pada tabel 2 .

Tabel 2. Ringkasan Uji Normalitas Data Posttest Siswa

\begin{tabular}{|c|c|c|c|c|}
\hline Data & Kelas & $\mathrm{L}_{0}$ & $\mathrm{~L}_{\text {tabel }}(\alpha=0,05)$ & Kesimpulan \\
\hline 40 & Eksperimen 1 & 0,06371 & 0,140089 & Normal \\
\hline 40 & Eksperimen 2 & 0,121916 & 0,140089 & Normal \\
\hline
\end{tabular}

Dari tabel di atas terlihat bahwa hasil uji normalitas pada taraf signifikansi $\alpha=0,05$ menunjukkan data posttest dari kedua sampel memiliki sebaran data yang berdistribusi normal. Hal ini diperoleh dengan membandingkan nilai signifikansi hasil perhitungan dengan $\alpha$ yang telah ditetapkan. Nilai signifikansi posttest pemahaman konsep matematika siswa pada kelas eksperimen 1 adalah $\mathrm{L}_{0}(0,06371)<\mathrm{L}_{\text {tabel }}(0,140089)$ yang berarti data berdistribusi normal dan pada kelas eksperimen 2 adalah $\mathrm{L}_{0}$ $(0,121916)<\mathrm{L}_{\text {tabel }}(0,140089)$ yang juga berarti data berdistribusi normal.
Sehingga dapat disimpulkan bahwa data posttest pemahaman konsep matematika siswa kedua kelas berdistribusi normal.

\section{Uji Homogenitas}

Hasil perhitungan uji homogenitas data dengan menggunakan uji F. Jika $\mathrm{F}_{\text {hitung }} \geq \mathrm{F}_{\text {tabel }}$ maka $\mathrm{H}_{0}$ ditolak atau kedua varians berbeda. Sedangkan jika $\mathrm{F}_{\text {hitung }}<\mathrm{F}_{\text {tabel }}$ maka $\mathrm{H}_{0}$ diterima atau kedua varians homogen. Dengan derajat kebebasan pembilang $=\left(\mathrm{n}_{1}-1\right)$ dan derajat kebebasan penyebut $=\left(n_{2}-1\right)$ dengan taraf nyata $\alpha=0,05$. Ringkasan hasil uji homogenitas disajikan pada tabel 3.

Tabel 3. Ringkasan Perhitungan Uji Homogenitas

\begin{tabular}{|c|c|c|c|c|}
\hline Kelas & Varians & $\mathrm{F}_{\text {hitung }}$ & $\mathrm{F}_{\text {tabel }}$ & Kesimpulan \\
\hline Eksperimen 1 & 198,5103 & \multirow{2}{*}{1,0249} & 1,697 & Homogen \\
\hline Eksperimen 2 & 193,6865 & & & \\
\hline
\end{tabular}

Berdasarkan Tabel 3 diperoleh $F_{\text {hitung }}(1,0249)<F_{\text {tabel }}(1,697)$ yang artinya varians nilai posttest pemahaman konsep matematika siswa kedua kelas sama atau homogen. homogenitas telah menunjukkan bahwa data posttest pemahaman konsep matematika pada kedua kelas berdistribusi normal dan varians kedua kelas juga sama atau homogen, oleh karena itu dilakukan pengujian hipotesis

\section{Uji Hipotesis}

Nina Richi N, Mukhtar. Perbedaan Kemampuan Pemahaman Konsep Matematika Siswa Menggunakan Model Pembelajaran Problem Based Learning dengan Model Pembelajaran Discovery Learning Berbantuan Cabri 3d di Kelas VII SMP Negeri 27 Medan. Jurnal Inspiratif, Vol. 3, No. 1 April 2017. 
menggunakan uji t sepihak. Hipotesis yang akan diujikan yaitu:

$\mathrm{H}_{\mathrm{o}}: \mu_{1} \leq \mu_{2}$

$\mathrm{H}_{\mathrm{a}}: \mu_{1}>\mu_{2}$

Keterangan:

$\mu_{1}$ : Rata - rata nilai postest siswa yang belajar dengan menggunakan model pembelajaran Problem Based Learning berbantuan Cabri 3D

$\mu_{2}$ : $\quad$ Rata - rata nilai postest siswa yang belajar dengan menggunakan model pembelajaran Discovery Learning berbantuan Cabri 3D.

Setelah diberikan perlakuan maka diperoleh nilai posttest kelas eksperimen 1 dengan nilai rata-rata 76,95 dan nilai posttest kelas eksperimen 2 dengan nilai rata-rata 68,175 . Ringkasan perhitungan uji hipotesis kelas eksperimen 1 dan kelas eksperimen 2 ditunjukkan pada tabel 4 .

Tabel 4. Ringkasan Perhitungan Uji Hipotesis Data Posttest

\begin{tabular}{|c|c|c|c|c|c|}
\hline \multirow{2}{*}{$\begin{array}{c}\text { Uji } \\
\text { sepihak }\end{array}$} & Data Kelas & $\begin{array}{c}\text { Nilai Rata- } \\
\text { Rata }\end{array}$ & $\mathrm{t}_{\text {hitung }}$ & $\mathrm{t}_{\text {tabel }}$ & Kesimpulan \\
\cline { 2 - 6 } & Eksperimen 1 & 76,95 & \multirow{2}{*}{2,802368} & 1,66462 & \multirow{2}{*}{ Tolak $\mathrm{H}_{0}$} \\
\cline { 2 - 6 } & Eksperimen 2 & 68,175 & & \\
\hline
\end{tabular}

Berdasarkan tabel 4. di atas, hasil pengujian pada taraf signifikansi $\alpha$ $=0,05$ dan $\mathrm{dk}=\mathrm{n}_{1}+\mathrm{n}_{2}-2=78$ dengan $\mathrm{t}_{\text {hitung }}=2,802368$ dan $\mathrm{t}_{\text {tabel }}=1,66462$ sehingga terlihat $t_{\text {hitung }}(2,802368)>$ $t_{\text {tabel }}(1,66462)$ yang berarti bahwa $\mathrm{H}_{\mathrm{o}}$ ditolak dan $\mathrm{H}_{\mathrm{a}}$ diterima. Sehingga disimpulkan bahwa rata - rata nilai postest siswa yang belajar dengan menggunakan model pembelajaran Problem Based Learning berbantuan Cabri $3 D$ lebih tinggi dibandingkan rata - rata nilai postest siswa yang belajar dengan menggunakan model pembelajaran Discovery Learning Berbantuan Cabri 3D.

\section{Pembahasan}

Penelitian yang dilakukan di kelas VIII SMP Negeri 27 Medan ini melibatkan dua kelas eksperimen 1 dan eksperimen 2. Kedua kelas diberi perlakuan yang berbeda. Kelas eksperimen 1 diberi perlakuan dengan menggunakan model pembelajaran Problem Based Learning dan kelas eksperimen 2 diberi perlakuan dengan menggunakan model pembelajaran Discovery Learning, dimana kedua kelas dalam pembelajarannya sama- sama menggunakan bantuan Sofware Cabri $3 D$.

Perbedaan model pembelajaran Problem Based Learning dan model pembelajaran Discovery Learning yang paling mendasar adalah pada model pembelajaran Problem Based Learning, pembelajarannya berdasarkan masalah dan dimulai dari masalah kehidupan nyata yang memberikan kesempatan pada siswa dalam memilih dan melakukan penyelidikan agar dapat memecahkan masalah tersebut. Sementara model pembelajaran Discovery Learning, pembelajarannya memanfaatkan pengetahuan sebelumnya dan mengaitkannya untuk menemuan suatu jawaban dari pernyataan/ masalah yang dimilikinya.

Setelah diberi perlakuan yang berbeda pada kelas eksperimen 1 dan kelas eksperimen 2, kemudian kedua kelas diberikan posttest atau tes akhir untuk megetahuan kemampuan pemahaman konsep matematikanya. Posttest yang diberikan kepada dua kelas adalah sama dan mengacu kepada indikator dari pemahaman konsep matematika siswa yaitu kemampuan translasi, interpretasi dan ekstrapolasi. Secara keseluruhan dari hasil posttest

Nina Richi N, Mukhtar. Perbedaan Kemampuan Pemahaman Konsep Matematika Siswa Menggunakan Model Pembelajaran Problem Based Learning dengan Model Pembelajaran Discovery Learning Berbantuan Cabri 3d di Kelas VII SMP Negeri 27 Medan. Jurnal Inspiratif, Vol. 3, No. 1 April 2017. 
yang ada diperoleh rata-rata nilai posttest kemampuan pemahaman konsep matematika siswa kelas eksperimen 1 yaitu 76,95 lebih tinggi daripada ratarata nilai posttest kemampuan pemahaman konsep matematika siswa kelas eksperimen 2 yaitu 68,175.

Hal di atas dibuktikan dengan dilakukannya pengujian hipotesis dengan menggunakan uji $\mathrm{t}$ satu pihak. Setelah dilakukan uji hipotesis pada data posttest pemahaman konsep matematika siswa, secara statistik diperoleh $t_{\text {hitung }}(2,8034)>t_{\text {tabel }}(1,66462)$ yang berarti bahwa $\mathrm{H}_{\mathrm{o}}$ ditolak dan $\mathrm{H}_{\mathrm{a}}$ diterima. Sehingga disimpulkan bahwa rata-rata postest siswa yang diajar dengan model pembelajaran Problem Based Learning berbantuan Cabri 3D lebih tinggi dibandingkan rata-rata postest siswa yang diajar dengan model pembelajaran Discovery Learning Berbantuan Cabri 3D.

Dengan merujuk pada nilai rata- rata posttest pemahaman konsep matematika siswa kedua kelas eksperimen terlihat bahwa nilai rata- rata pemahaman konsep kelas eksperimen 1 lebih tinggi dibandingkan dengan kelas eksperimen 2. Hal ini menunjukkan bahwa pembelajaran matematika dengan menggunakan model pembelajaran Problem Based Learning lebih baik dibandingkan model pembelajaran Discovery Learning. Hal ini dikarenakan model Problem Based Learning merupakan pembelajaran yang mendorong siswa untuk melakukan evaluasi sendiri baik terhadap hasil maupun proses belajarnya, mengembangkan kemampuan siswa untuk berfikir kritis dan untuk menyesuaikan dengan pengetahuan baru, memberikan kesempatan bagi siswa untuk mengaplikasikan pengetahuan yang mereka miliki dalam dunia nyata, mengembangkan minat siswa untuk secara terus menerus belajar sekalipun belajar pada pendidikan formal telah berakhir dan memudahkan siswa dalam menguasai konsep-konsep yang dipelajari guna memecahkan masalah dunia nyata. Selain itu dalam model pembelajaran Problem Based Learning fase demi fase yang lebih terstruktur dan sistematis dibandingkan dengan model pembelajaran Discovery Learning.

Meskipun demikian, baik Problem Based Learning maupun Discovery Learning sama- sama dapat menjadikan siswa terbiasa aktif dalam menyelesaikan masalah berpikir secara individual untuk mendapatkan konsep. Hal ini terjadi karena proses pembelajaran bukan hanya sekedar mentransfer ilmu dari guru kepada siswa, melainkan suatu proses yang dikondisikan atau diupayakan oleh guru, sehingga siswa aktif dengan berbagai cara membangun sendiri pengetahuannya. Dalam pembelajaran dengan model Based Learning dan model Discovery Learning sama- sama dapat meningkatkan kemampuan pemahaman konsep matematika di kedua kelas eksperimen tersebut. Hanya saja rata- rata hasil posttest di kelas dengan model pembelajaran Problem Based Learning lebih tinggi dibandingkan di kelas dengan model pembelajaran Discovery Learning.

Hasil penelitian ini sejalan dengan beberapa hasil penilitian terdahulu yaitu May (2016) yang menyimpulkan bahwa hasil belajar matematika yang dikenai dengan Problem Based Learning mempunyai tingkat kemampuan berpikir kreatif yang lebih baik dibandingkan dengan hasil belajar matematika siswa yang dikenai dengan Discovery Learning. Selain itu Minarni (2016) juga melakukan penelitian yang sejalan dengan simpulan bahwa model pembelajaran Problem Based Learning dapat meningkatkan kemampuan pemahaman matematika siswa dan meningkatkan aktivitas siswa didalam kegiatan pembelajaran. Sehingga model pembelajaran PBL

Nina Richi N, Mukhtar. Perbedaan Kemampuan Pemahaman Konsep Matematika Siswa Menggunakan Model Pembelajaran Problem Based Learning dengan Model Pembelajaran Discovery Learning Berbantuan Cabri $3 d$ di Kelas VII SMP Negeri 27 Medan. Jurnal Inspiratif, Vol. 3, No. 1 April 2017. 
lebih baik digunakan untuk kemampuan pemahaman konsep matematika siswa.

\section{Kesimpulan}

Dari hasil analisis yang dilakukan dalam penelitian ini diperoleh kesimpulan bahwa kemampuan pemahaman konsep matematika siswa yang belajar dengan model pembelajaran Problem Based Learning berbantuan Cabri $3 D$ lebih tinggi dibandingkan siswa yang belajar dengan model pembelajaran Discovery Learning Berbantuan Cabri $3 D$ di kelas VIII SMP Negeri 27 Medan.

\section{Saran}

1. Bagi guru matematika disarankan untuk dapat mengajarkan materi kubus dan balok dengan menggunakan model pembelajaran yang mengajak siswa untuk menemukan sendiri konsep kubus dan balok sehingga dapat meningkatkan pemahaman konsep matematika siswa. Oleh karena itu kepada guru dapat diharapkan menambah wawasan dan pengetahuan terhadap model pembelajaran Problem Based Learning dan model pembelajaran Discovery Learning yang memungkinkan untuk diterapkan sebagai usaha dalam meningkatkan kemampuan pemahaman konsep matematika siswa.

2. Kepada siswa SMP Negeri 27 Medan disarankan lebih berani dalam menyampaikan pendapat atau ide-ide dan mempergunakan seluruh perangkat pembelajaran sebagai acuan yang dapat membuat siswa menjadi lebih aktif sehingga guru dapat melibatkan siswa dalam pembelajaran.

3. Kepada penelitian lanjutan agar hasil dan perangkat penelitian ini dapat dijadikan pertimbangan untuk menerapkan model pembelajaran Problem Based Learning dan model pembelajaran Discovery Learning pada materi kubus dan balok ataupun materi yang lain serta dapat dikembangkan untuk penelitian selanjutnya untuk mendapatkan hasil yang lebih baik yang dapat meningkatkan mutu pendidikan.

\section{DAFTAR PUSTAKA}

Christou,C., dkk, (2006), Developing the 3DMath Dynamic Geometry Sofware: Theoretical Perspectives on Design, International Journal for Technology in Mathematics Education, 13(4), 168-174.

Depdiknas, (2014), Peraturan Mentri Pendidikan dan Kebudayaan No. 58 Tahun 2014 tentang Kurikulum SMP, Depdiknas, Jakarta.

Dewi, Vera, (2014), Peningkatan Kemampuan Pemahaman Matematik dan Sikap Positif Terhadap Matematika Siswa Nasrani 2 Medan Melalui Pendekatan Problem Posing, Jurnal Saintech, 6, 2086-9681

Hosnan, (2014), Pendekatan Saintifik dan Kontekstual dalam Pembelajaran Abad 21, Ghalia Indonesia ,Bogor.

Hudojo, (2005), Pengembangan Kurikulum dan Pembelajaran Matematika, Universitas Negeri Malang, Malang.

Minarni, Ani, dkk, (2016), Mathematical Understanding and Representation Ability of

Nina Richi N, Mukhtar. Perbedaan Kemampuan Pemahaman Konsep Matematika Siswa Menggunakan Model Pembelajaran Problem Based Learning dengan Model Pembelajaran Discovery Learning Berbantuan Cabri 3d di Kelas VII SMP Negeri 27 Medan. Jurnal Inspiratif, Vol. 3, No. 1 April 2017. 
Public Junior High School in North Sumatra, Journal on Mathematics Education, 7(1), 2087-8885.

Murizal, dkk, (2012), Pemahaman Konsep Matematis dan Model Pembelajaran Quantum Teaching, Jurnal Pendidikan Matematika, 1(1).

Rahayu, dkk, (2015), Eksperimentasi Model Problem Based Learning dan Discovery Learning Pada Materi Perbandingan dan Skala Ditinjau dari Sikap Peserta Terhadap Matematika Didik
Kelas VII SMP Kabupaten Klaten Tahun Pelajaran 2013/ 2014, Jurnal Elektronik Pembelajaran Matematika, 3(3), 2339- 1685.

Rusman, (2012), Model- Model Pembelajaran Pengembangan Profesionalisme Guru, PT. Raja Grafindo Persada, Jakarta.

Widiayaningsih, (2013) Keefektifan Pembelajaran Model Quantum Teaching Berbantuan Cabri 3D Terhadap Kemampuan Pemecahan Masalah. Jurnal Kreano. 4 (1), 2086-2334.

Nina Richi N, Mukhtar. Perbedaan Kemampuan Pemahaman Konsep Matematika Siswa Menggunakan Model Pembelajaran Problem Based Learning dengan Model Pembelajaran Discovery Learning Berbantuan Cabri 3d di Kelas VII SMP Negeri 27 Medan. Jurnal Inspiratif, Vol. 3, No. 1 April 2017. 